\title{
ORÍGENES: CONCEPÇÃO DO SABER, PLANO E MÉTODO
}

Joăo Lupi*

SÍNTESE - Orígenes é o primeiro pensador e mestre cristão sobre cuja obra escrita sistemática e ensino institucional é possivel fazer uma apreciação criteriosa. Seu plano de estudos, por toda a vida, tem a Escritura como objeto único, enquadrado entre uma visão teórica integral e um destino apologético. A Sabedoria é o Logos, Cristo, e por isto a ciência total é a Teologia. O plano teórico do saber abrange a tríplice realidade: Deus, Mundo, Homem; e o programa de estudos segue este plano. Mas nem o plano nem o programa são rígidos, suas temáticas se interpenetram. O método de análise baseia-se no estudo literal do texto e a interpretação é alegórica ou literal; sua pedagogia tem como aspecto principal o exemplo da vida filosófica dado pelo mestre.

PALAVRAS-CHAVE - Orígenes, ciência, Filosofia patrística.
ABSTRACT - Origen's written work and his institutional teaching are the first among early Christian Fathers which we are able to discuss and appreciate with a sound judgment. Holy Scripture was his sole subject for life, but this design was framed between a broad and highly intelectual insight and an apologetical scope. Wisdom is Logos the Christ; therefore Theology is the whole-comprising science. His theoretical plan covered a threefold reality: God, the World, and Man; his courses can be understood according to these guide-lines, however intrincate their subject-matters were. Lexical analysis of texts was the ground for Origen's method of allegorical or spiritual interpretation. As a pedagogue he showed a philosophical behaviour as the main example for his disciples.

KEY WORDS - Origen, science, philosophical patristic.

1. Orígenes (185-253) foi o primeiro pensador e escritor de uma grande obra sistemática sobre o conjunto da doutrina cristã, e ao mesmo tempo o primeiro diretor de estudos de instituições de ensino de caráter permanente do Cristianismo - no didaskalion de Alexandria, e na escola que ele mesmo criou em Cesaréia da Palestina. Se outros houve antes dele, por exemplo Panteno e Clemente seus antecessores no didaskalion, certamente de nenhum deles dispomos de uma obra tão vasta, e de tantos testemunhos contemporâneos, com temos de Orígenes; são estes testemunhos e esta obra que nos permitem defini-lo não só como o primeiro, mas como um dos mais influentes mestres e escritores do Ocidente nos séculos seguintes pelo menos até João Escoto Eriúgena. E certamente nenhum dos primeiros doutores cristãos entusiasmou de tal modo seus discípulos por

* Universidade Federal de Santa Catarina - UFSC.

\begin{tabular}{|l|l|l|l|l|l|}
\hline VERITAS & Porto Alegre & v. 43 & $\mathrm{n}^{0} 3$ & Setembro 1998 & p. $475-482$ \\
\hline
\end{tabular}


tantas gerações, ao ponto de se deixarem perseguir e condenar dentro da Igreja por adotar as doutrinas de Orígenes. Mas a partir do século VI seus discípulos no Ocidente diminuíram, suplantada que foi sua influência pela autoridade de Agostinho, pelas críticas feitas por uma dogmática mais excludente, e mais tarde pelas doutrinas mais consistentes da escolástica. No século XX vimos finalmente a reabilitação de Origenes, por obra de alguns teólogos jesuítas: Lubac, Daniélou, Crouzel, Mondésert, Doutreleau, Borret. Como disse Eusébio (História da Igreja, VI, 3, 7): "E assim [Orígenes] conduziu uma multidão a partilhar do seu entusiasmo." Para apresentar e discutir a concepção de saber deste mestre, e seus planos de trabalho e de ensino dispomos dos seguintes principais elementos: o tratado mais sistemático de Orígenes, conhecido como Peri Arxon, ou Tratado dos principios (redigido a partir de 229), onde ele mesmo expõe em diversas passagens seus métodos e diretrizes; a História da Igreja de Eusébio de Cesaréia (escrita por volta de 324) que dedica quase todo o sexto capítulo à exposição da vida e obra do mestre; e o Discurso de agradecimento pronunciado em 241 por seu discípulo Gregório ao despedir-se da escola de Cesaréia e onde ele expõe o método e concepção de ensino de Orígenes. ${ }^{1}$

2. Conhecemos a vida e a obra de Orígenes em grande parte por testemunhos e por citações, porque muito do que ele escreveu se perdeu. Mesmo assim, muito ainda ficou, o suficiente não só para colher de seus ensinamentos uma argumentação viva, sólida, e completa, mas também para nos impressionarmos com uma visão marcante: a de que ele tinha um plano de estudos para a vida toda, e de que o preencheu totalmente. Um pouco esquematicamente podemos dizer que este plano começou pelo Peri Arxon, uma obra sistemática - não por ser estruturalmente fechada, mas pela sua abrangência e concepção de conjunto, englobando toda a doutrina cristã a partir de seus princípios fundamentais e apostólicos; que esta definição inicial do quadro geral de entendimento foi seguida pela análise criteriosa de todos os livros da Escritura - tanto na exegese alegórica dos comentários como na aplicação moral das homilias - análise que consumiu a imensa maioria de seu trabalho de estudioso e de mestre; e que o plano foi concluido por uma nova obra sistemática, o Contra Celso, redigida em 248 pouco antes de ir para a prisão e morrer. Dissemos que esta é uma visão esquemática do plano de estudos da vida de Orígenes porque algumas obras, e não das menos importantes, ele redigiu antes do Peri Arxon, e pelo menos um pequeno comentário foi escrito depois do Contra Celso; mas também é certo que o período mais fecundo da vida de Orígenes se situa entre uma e outra obras sistemáticas, quando residiu em Cesaréia entre 230 e 250, com algumas interrupções. Por isso não é inadequado dizer que entre as duas obras de conjunto, a primeira dogmática, e a última apologética, fica o imenso trabalho de análise, no qual podemos distinguir três partes, uma vez que os comentários e as homilias foram precedidos pelo monumental estudo comparativo da Bíblia; nele Orígenes colocou lado a lado as quatro tradu-

1 Discute-se se este Gregório é, ou não, o Taumaturgo - Crouzel diz que sim, e com ele Merino; Moreschini e Norelli dizem que é muito provável, mas Simonetti acha que talvez seja; a dúvida foi lançada por Nautin, que diz tratar-se de outra pessoa. 
Ções gregas em uso no seu tempo - na versão das Tétraplas; e na versão das Héxaplas comparou-as ainda com o texto hebraico e com sua transcrição grega; para finalmente em alguns livros acrescentar mais duas traduções: as Óctoplas. Deste modo Orígenes analisou o texto da Bíblia letra a letra, não se contentando com a versão dos Setenta, mas inclusive buscando ou mandando vir manuscritos hebraicos onde quer que fossem encontrados (Eusébio, VI, 16, 3). Todo este trabalho documental visava estabelecer o texto mais fiel ao original, e só depois dele é que o autor se sentiu seguro para empreender o estudo interpretativo da Escritura. Infelizmente por serem volumes demasiado grandes, decerto foram feitas poucas cópias, e delas só alguns fragmentos chegaram até nós. Temos assim testemunhado o ambicioso, mas cumprido plano de todo o saber de Orígenes, embasado numa visão integral de conjunto, apoiado na análise e comparação literais, explicado e aplicado minuciosamente e extensissimamente no estudo das Escrituras, e finalmente concluido pela defesa doutrinal. Dificilmente se encontrará, em toda a história do pensamento universal, uma concepção de saber mais completa na sua variedade, e tão integralmente realizađa por um só homem.

3. A concepção de saber de Orígenes é nitidamente teológica, platônica e realista: o saber existe, e é a Sabedoria que é a pessoa de Cristo. Cristo é a Sabedoria de Deus que existe antes do mundo; todo e qualquer saber é saber Cristo e em Cristo. Por isso para os homens a Sabedoria é conhecer a Cristo, pois Ele é a via pela qual se chega a Deus (Peri Arxon I,2, 4-5). Daí o dizer que Deus, àqueles que quer tornar racionais, dá-Ihes a palavra e a razão, pela participação em Cristo (ib. I, 3, 7). E, segundo o testemunho de Gregório (Discurso, 150) para Orígenes o mais necessário de tudo é conhecer o autor de todas as coisas. O saber é pois um ato ontológico e divino, ou de divinização, na medida em que é uma participação na Sabedoria que é Deus. Ora talvez seja interessante, para explicitar esta concepção de saber, diferenciá-la de outra, também ontológica e platônica: a de Plotino. Para Orígenes, segundo o Discurso de Gregónio (35-36) a Palavra Primogênita de Deus, artífice e governante do universo [...] é a Verdade, a Sabedoria e o poder do Pai do universo; [ela él a Palavra animada pela própria Inteligência primeira (ib.39). Vemos aqui uma identificação entre a Inteligência e o governo do universo que não existe no neo-platonismo. Na concepção neoplatônica das Enéadas não existe Logos, como Palavra e Razão, mas Nous, que é Verdade e Inteligência em si mesma, emanação imediata do Uno. Inferior a ela é a Alma do Mundo, que forma e governa o mundo; portanto a Sabedoria não está em contato direto com o homem, ela é contemplada pela Alma que governa o mundo; e sendo assim, a sabedoria humana no seu nivel mais alto só pode ser alcançada individualmente transpondo o mundo e entrando, pelo êxtase, em contato direto e pessoal com o Uno. É neste êxtase que consiste a verdadeira e última sabedoria. Não é assim para Orígenes, para quem a Sabedoria é o Verbo divino que se revelou diretamente aos homens, e portanto conhecer a palavra revelada é ter acesso à Sabedoria sem necessidade de êxtase. O saber é pois acessivel a todos, desde que se faça o esforço do estudo, se tenha um bom guia, um mestre (um pedagogo), e se receba assistência do Espirito Santo - que não corresponde à Alma do Mundo neoplatônica. O mestre, diz Gregório (ib. 179) conhece e orienta porque recebe seu saber pela comunicação do 
Espírito Divino. O Discurso de Gregório é porém menos democrático: elogiando o seu mestre diz que o Logos não se revela a todos igualmente, mas a alguns em especial, e particularmente a Orígenes: "A Divindade lhe concedeu bens (de conhecimento) só a ele, mais do que à maioria dos homens" (82). Esta diferença em relação ao neoplatonismo aparece também em Gregório quando ele fala do homem como reflexo da divindade e diz (87): "a alma nasceu, em primeiro lugar, para. estar onde está a inteligência [...] e só pode estar de forma total e absoluta onde estiverem as obras que the são próprias e suas". Há portanto uma fonte racional e direta da Ética, quando se associa a inteligência às obras da alma, o que não acontece nas Enéadas.

4. O plano de conjunto do Tratado dos princípios apresenta-se como uma visão total e integrada da realidade que se pode conhecer. No entanto discute-se interminavelmente - é um dos assuntos prediletos de debate entre os origenistas atuais - qual seja este plano. De fato existem inúmeras tentativas de descobrir o verdadeiro plano do Peri Arxon, algo que não esteja evidente mas seja o pano de fundo de toda a obra. Nestas condições, apresentar as razões pelas quais defenderíamos o plano subjacente mais correto estaria para além deste trabalho. Mas do muito que já se discutiu podemos destacar o que vem ao nosso propósito: 1. o Peri Arxon tem uma unidade de redação e uma articulação interna que só podem ser o resultado de uma intenção de conjunto: o autor tem uma introdução para cada parte e assunto, faz a passagem de um tema para outro, conclui as questões, isto é, constrói uma armação do discurso todo; 2. a obra tem mais de um plano, tanto do ponto de vista sistemático como didático, porque o autor indica no prefácio vários temas principais, mas a divisão das partes não lhes corresponde fielmente, além de o texto ser redigido com muitas repetições, e temas fora do lugar; 3 . a quarta parte - sobre o método de análise da Escritura - não tem uma seqüência clara em relação com o plano teórico da obra, de tal modo que nenhum intérprete consegue enquadrá-la nas outras três - ou ao menos não o faz de modo a que os outros origenistas concordem. Tudo isto evidencia que o autor tinha idéias de fundo que não conseguiu explicitar. Sem, portanto, pretender resolver todos os problemas, fixemo-nos no plano que Fócio (séc. IX) apresenta na sua edição do Peri Arxon (Bibliotheca). O título do 1ำ tomo, nesta edição, é A propósito do Pai, do Filho, e do Espírito Santo e prossegue: e acerca das naturezas racionais vindo o tomo $2^{\underline{Q}}$ com o título: O mundo e as criaturas que aí se encontram; mas este plano não abrange o total da obra de uma forma linear, porque ainda no $2^{\circ}$ tomo volta a falar de Deus, e no $3^{\circ}$ trata do homem e de outras criaturas. A divisão em capítulos remonta à Filocalia organizada pelos Capadócios; ela foi completada pelos copistas, e sistematizada na edição de Koetschau (1913); nela encontramos 25 subtítulos (mais 4 sobre as Escrituras) que sem dúvida podem ser agrupados no mesmo esquema: Deus - Mundo - Homem, mas sem uma seqüência linear: Deus (I, 1-3; e II, 4-7); Mundo (I, 4-8; II, 1-3; 8-11; III, 5-6); Homem (III, 1-4) sendo que neste agrupamento pode haver muitas dúvidas: criaturas racionais inclui os anjos, e nesta divisão eles fazem parte do mundo espiritual - e o homem, fica com os anjos nos racionais, ou fica no mundo físico? Parece que, mais do que separar, as divisões possíveis de verificar articulam a realidade. Ou seja, os tratados mostram uma certa independência, sem estarem colocados numa ordem muito rígida; eles 
estão agrupados de tal forma que indicam diversos tipos de relações entre si, podendo encaixar-se no esquema tripartido, mas não têm um plano único evidente. Aliás o esquema tripartido é também do próprio Orígenes, que no prefácio apresenta os nove pontos da pregação apostólica: Deus - Cristo - o Espírito Santo; alma - ressurreição - livre arbítrio; o diabo - os seus anjos - e o mundo; ao que acrescenta as Escrituras. Pode-se considerar ainda (Harl, em Origeniana, cf. Crouzel) um plano geral em dois ciclos, o primeiro mais especulativo (desde I,1 até II,3) que trataria de Deus, das criaturas racionais, e do mundo e suas criaturas; e outro mais próximo aos assuntos quotidianos e práticos da Igreja (o restante) que trata das Três Pessoas da Trindade, do que se refere à vida humana, e do que se refere às criaturas racionais e ao mundo. Em qualquer caso, a tríade Deus - Homem Mundo é o conjunto mais evidente para agrupar os temas.

5. O programa de estudos das escolas em que Orígenes ensinou é razoavelmente conhecido, mas sem muitos detalhes, e com algumas dúvidas, o que é próprio de uma instituição sem um currículo fixo, em que o corpo docente se identifica com o mestre, e o programa é sua própria doutrina. Sabemos, por outro lado, que desde a fundação do Museu e da Biblioteca de Alexandria por Ptolomeu Soter - primeiro faraó macedônio - até ao incêndio da Biblioteca provocado por Júlio César, a especialidade dos alexandrinos era a crítica literária, mas que a partir do domínio romano (esta periodização é um pouco incerta) as ciências ditas naturais passaram a ser a característica dos estudos em Alexandria. Por isso não é de estranhar que na análise de textos Orígenes siga uma tradição judaica, a de Filon, e não a dos estudiosos de Homero; e, por outro lado, que tenha dado importância ao estudo da natureza, posto que muitos de seus discípulos no didaskalion conheciam o que nós chamamos de ciências. Quando, pela grande afluência de alunos, teve de dividir as aulas com Héraclas, Orígenes ficou com a geometria e a astronomia; e assim continuou anos mais tarde em Cesaréia da Palestina, pois no dizer de Gregório (Discurso 114) o fundamento do estudo da natureza ele colocava na geometria - "por ser um seguro alicerce a geometria era a base de todo o estudo"; mas o último e principal estágio deste estudo era a astronomia. Mais ou menos o mesmo diz Eusébio (História da Igreja, 18, 3-4) que a estas ciências acrescenta a aritmética. Pode-se constatar no Tratado dos princípios que Orígenes aceitava e ensinava 0 conhecimento comum da Antigüidade acerca da matéria e dos elementos, dos corpos, do movimento e do tempo, e outras questões relacionadas com estas. Não se detém, contudo, na sua explicação, apenas as considera na medida em que são necessárias para resolver os problemas doutrinais. Quanto à gramática e literatura diz Eusébio (ib. 3,8) que ele era muito versado, mas que quando começou a ensinar no didaskalion as deixou de lado; há que entender que Orígenes teria vendido seus volumes de literatura clássica (pagã) quer porque precisava de dinheiro (os bens da família tinham sido confiscados quando o pai foi preso na perseguição aos cristãos) quer porque diante dos novos encargos de ensino catequético a literatura pagã não lhe interessava mais. Mas a gramática, no sentido atual de estudo da linguagem, certamente ele não abandonou; o próprio Eusébio diz que Orígenes estudou hebraico (ib. 16,1) e se dedicou com afinco aos problemas de tradução. Basta ver os comentários que ainda temos (fora os muitos 
que se perderam) para perceber o quanto Orígenes era perito em filologia, em muitos aspectos que incluimos hoje como lingüística, e de modo geral na gramática e na análise de textos, que com certeza também ensinava. Quanto à filosofia, que em grande parte inclui muito do que já indicamos como ciências da natureza e ciências da linguagem, era sempre matéria integrante do seu ensino e plano de estudos. Todas as filosofias gregas eram estudadas por Orígenes com seus discípulos (Discurso 151-154) sem conceder mais atenção a uma do que a outra, apenas deixando de lado aquelas que defendiam a não existência divina, ou recusavam a Providência. Aparte esta restrição, o mestre queria que seus alunos "não deixassem de conhecer nenhuma opinião dos gregos" (Discurso, 170) e por isso "percorríamos e investigávamos todas as opiniões" (ib. 182). Gregório diz-nos ainda um pouco mais sobre o método de estudo da filosofia: Origenes prestava atenção ao vocabulário de cada doutrina (ib. 135) procurando o significado correto, mais do que a elegância (136) - talvez esteja também aqui aquela diferença que assinalamos entre gramática e literatura; mas para além disso procurava, na discussão dos argumentos, distinguir aqueles que eram compativeis com a teologia cristã, daqueles que não o eram (ib. 172-173). Eusébio (op. cit. 18, 3-4) também nos fala dos estudos de filosofia nas escolas de Orígenes, e embora não entre em detalhes, seu relato não diverge do de Gregório. Por outro lado, aquilo que estes dois testemunhos apresentam em resumo e em linhas gerais, pode ser fartamente ilustrado pelas duas obras sistemáticas (Tratado dos princípios e Contra Celso) onde 0 autor demonstra continuamente seu conhecimento das filosofias clássicas, e até sobre as teorias físicas do epicurismo, das quais dizia que por revelarem impiedade (asebeia) não se deveria falar.

6. Muito do que sabemos sobre o método de Orígenes - à parte, é claro, o que se pode saber investigando a estrutura de suas obras - vem-nos do testemunho de Gregório; este, no seu entusiasmo um tanto florido, começa por abusar das metáforas (Discurso, 93-100) como: "os discípulos éramos como terra estéril e salobra [...] e o mestre como um jardineiro nos enxertou um ramo novo (93) e quando encontrava em nós algo de útil, proveitoso e eficaz (com sua técnica de lavrador) escavava e removia a terra [...] e com toda sua arte e cuidado nos cultivava" (9596). Embora nos digam muito sobre o zelo e sobre a paciência pedagógica de Orígenes, estas metáforas são pouco explícitas, mas outras passagens são mais claras. Parece, por exemplo, que ele se empenhava em fazer prevalecer a razão sobre os devaneios desarrazoados, que o próprio Gregório compara aos de "potros selvagens que saltam e correm fora do caminho" (97). Este controle da argumentação, diz Gregório que ele empregava como uma purificação geralmente difícil (98). A didática era lenta e bem escolhida, "cada coisa a seu tempo e com palavras adequadas" (99). A argumentação empregada era também cuidadosa, partindo "dos princípios simples e articulando as palavras e raciocínios de forma variada, de maneira a construir uma trama bem completa" (101). Esta era a parte expositiva das aulas de Orígenes, mas uma outra parte importante das aulas consistia na exposição de opiniões distintas, por parte dos alunos, as quais Orígenes ia rebatendo mostrando a falta de juízo crítico dos discípulos apressados - tão depressa aceitavam testemunhos sem valor, como recusavam idéias que depois se verifica- 
va serem as melhores (102-104). Cuidava sobretudo para que os jovens não se deixassem enganar por uma bela expressão retórica, mas sem argumento sólido, contra uma boa razão apresentada sem a correta dicção helênica (106-108). Muito já tem sido escrito sobre o método de Orígenes, tanto nả exposição didática (cf. Nunes) como na investigação e na exposição teórica (por exemplo: Lubac). Para o nosso objetivo basta-nos aqui lembrar que Orígenes exigia sempre três passos na investigação: o primeiro era o estabelecimento do texto correto, literalmente exato - cf. o que dissemos a propósito das Héxaplas; o segundo requeria que se ultrapassasse a letra - e ele dá exemplos de como o sentido literal da Escritura é insustentável, como no caso dos dias da criação do Gênesis; e o terceiro procura o sentido mais profundo e completo, que só pode ser obtido se se considerar o texto como sendo uma alegoria - ou repleto de alegorias. Para chegar aí, diz ele, é preciso começar por aplicar o senso comum e o conhecimento das evidências, mas também a fé na palavra divina das Escrituras (Peri Arxon IV, 1, 1); seria estúpido (idiootikôon) diz ele, sabendo que a Escritura é divina não procurar nela o sentido espiritual, mas contentar-se com o literal (ib. IV, 2, 2) - e por não cuidar disso alguns cairam em erros (ib. IV, 2, 1). É preciso procurar o que está oculto na letra, tanto no relato histórico, como no doutrinário ou normativo (IV, 2, 8 e 9). Para ter uma idéia completa do pensamento de Orígenes sobre estes temas é preciso lembrar que foi precisamente esta uma das diretrizes que lhe valeu mais opositores, que negavam o sentido alegórico, espiritual, simbólico, ou místico da Escritura negação que se configurou na escola de Antioquia - o que ainda em vida o obrigou a muitas explicações.

7. Finalmente, assim como a Sabedoria se identifica com a Verdade divina do Logos, assim o saber se identifica com a vida do mestre. Ele tem que viver o que ensina, o que implica que seu ensinamento seja todo ele voltado para o sentido e diretrizes do modo de vida. Saber por curiosidade para Orígenes não tem sentido. O objetivo do estudo é a virtude e a felicidade: esta é a idéia que Gregório expõe longamente e de muitos modos (Discurso 115-126; e 137-144). "Elogiava a filosofia e os filósofos com grandes panegíricos, e fazia-lhes referências freqüentes, dizendo que só vivem realmente aqueles que levam sua vida em conformidade com a razão, os que vivem retamente; aqueles que em primeiro lugar se conhecem a si mesmos, e depois qual é o verdadeiro bem que se deve procurar, e qual o mal que se deve repelir" (ib. 75). Aliás, quem não estiver de bem consigo mesmo não pode se aproximar de Deus, o que para Orígenes seria o maior fracasso de uma vida: "quem não for filósofo não pode de jeito nenhum praticar a religião" (ib. 79). Era por este modo de vida que o mestre tinha sucesso: "ele atraía pela amizade, pela benevolência das suas palavras, e pela sua conversa como que nos hipnotizava diz ainda Gregório na despedida - sua boa intenção transparecia na habilidade e na caridade com que nos tratava, para que participássemos dos bens da filosofia" (ib. 80-81). O estudo é uma relação divina e o aprendizado com o mestre é, dentro desta relação, um estreitamento humano: aprendiamos, diz a despedida, "pelos sagrados laços da amizade" (ib. 89). Que, aliás, foi para Gregório um entusiasmo desde o primeiro dia em que conheceu o mestre, pois nada mais the interessou durante os oito anos na escola de Cesaréia, "a não ser a filosofia e esse homem divino, que era o meu mestre" (ib. 84). 


\section{Referências bibliográficas}

- de Origenes

Tratado dos princípios

Traité des Principes. Sources Chrétiennes n. 252, 253, 268, 269, 312, Trad. H. Crouzel e M. Simonetti, Les Éditions du Cerf, Paris: 1978-1984.

De Principiis. Ante-Nicene Fathers, vol. 4, 239-382, trad. Frederick Crombie, Hendrickson publ., Peabody, 1995 (1885).

Contra Colso

Against Celsus. Ante-Nicene Fathers, vol. 4, 395-669, trad. Frederick Crombie, Hendrickson Publ., Peabody, 1995 (1885).

Contre Celse. Sources Chrétiennes, n. 132, 136, 147, 150, 227, trad. Marcel Borret, Les Éditions du Cerf, Paris: 1967-1976.

Contra Celso. Trad. Daniel Ruiz Bueno, B. A. C., Madrid: 1967.

- de Gregório

Discurso de agradecimento

The Oration and Panegiric adressed to Origen. Ante-Nicene Fathers, vol. 6, 21-39, trad. S. D. F. Salmond, Hendrickson Pulb., Peabody, 1995 (1886).

Elogio del Maestro cristiano. Biblioteca de Patrística, trad. Marcelo Merino, Editorial Ciudad Nueva, Madrid: 1990

- de Eusébio

História da Igreja

The Church History. Nicene and Post-Nicene Fathers, vol. I, 81-387, trad. Arthur Cushman McGiffert, Hendrickson Publ., Peabody, 1995 (1890)

The History of the Church from Christ to Constantine. trad. G. A. Williamson, Barnes \& Nobie, Nova Iorque: 1995 (1965)

- Comentários

BOEHNER, Ph. \& GLSON, E. Históna da Filosofia Cristã. Trad. Raimundo Vier. Vozes, Petrópolis, 5. ed. 1991 (1952), 48-78.

MORESCHINI, Claudio, \& NORELLI, Enrico: História da Literatura Cristã Antiga Grega e Latina. Voì. I, 365-407, trad. Marcos Bagno. São Paulo: Loyola, 1996

NUNES, Ruy Afonso da Costa: História da Educação na Antigüidade Cristã. Editora da Universidade de São Paulo/ E. P. U., 1978, p. 121-142: Origenes, o mestre de Alexandria; e Origenes e o ensino.

OUASTEN, Johannes: Patrología. Vol. I, 351-411. Edição espanhola: Ignacio Oñatibia. B. A. C., Madrid: 1984 (1950).

- do autor

LUPI, João: A Escola de Alexandria como núcleo do helenismo cristão. Revista de Ciências Humanas (UFSC), 11, n.15, 1994, 11-23.

A concepção de mundo de Origenes. Reunião da SBPC, Vitória: 1994.

A Cosmologia de Orígenes. Pré-publicações do Departamento de Filosofia da UFSC, 1994.

O Significado de suntuxia em Origenes. Pré-publicações do Departamento de Filosofia da UFSC, 1996.

Origenes: a ordem do mundo e o acaso. Veritas (PUCRS), 42, n.3, 1997, 479-492.

From Origen's Peri Arxon to Eriugena's Peri Physeon. Congresso Internacional da STEPM. Erfurt, 1997.

Palavra e Escritura em Orígenes. Simpósio Nacional de Estudos Clássicos (SBEC), São Paulo: 1997. 